\title{
MANAGEMENT OF PALATINETONSILLOLITHS
}

\author{
(PENATALAKSANAAN BATU TONSILA PALATINA)
}

\author{
Winny Yohana \\ Oral Biology Department \\ Faculty of Dentistry Padjadjaran University \\ Jl. Sekeloa Selatan No.1 Bandung \\ E-mail: winny.yohana@fkg.unpad.ac.id
}

\begin{abstract}
Palatine Tonsilloliths are stones that lodged in tonsillar palatine crypt, tonsillolith are stones that caused by an accumulation of sulfur-producing bacteria, fungus, desquamated cells, food debris, and mucus that collect in the tonsillar crypts. Tonsillolith also known as tonsil stones, tonsillar concretion, or lith. Tonsilloliths have been recorded weighing from $0,3 \mathrm{~g}$ to $4 \mathrm{~g}$. They may be difficult to remove, but are usually not harmful. Tonsillolith can be unilateral or bilateral. Occurs in young adult and are rare in children. Etiology is unknown, it has been shown that the calcification develop with mass of desquamated epithelium, serum, food debris and bacterial colony. This case reports a patient with palatine tonsilloliths. A 55 years old female came to a private clinic, she complained difficult to swallow, sore throat, itching in right tonsillar, a foreign body-like sensation. On clinical examination, a superficial tonsillolith may be seen as white hard mass within the right tonsillar, tonsillar slightly inflammation. The tonsillolith size is $2 \times 3 \times 1 \mathrm{~mm}$. Treatment is usually removal of the tonsilliths by excavation tonsil stones and although mouthwash/ oral rinse without alcohol, antibiotic, gargling helps wound healing. After tonsillith excavated, a week later the wound healing is well. Her right palatine tonsil looks healthy, wound healing is normal no sore throat, prognosis is good. Healing will be perfect when eating soft food. Successful treatment depends on good cooperation between the patient and the doctor.
\end{abstract}

Key words: palatine tonsilloliths, sore throat, excavated

Tonsillolith Palatine adalah batu yang bersarang dalam kripta tonsilapalatina, tonsillolith adalah batuyang disebabkan oleh akumulasi bakteri yang menghasilkan sulfur, jamur, sel-sel yang mengalami deskuamasi, sisa makanan, dan lendir yang terkumpul di dalam kripta tonsil. Tonsillolith juga dikenal sebagai batu amandel, batu tonsila, atau lith (batu). Tonsilloliths telah ditemukan dengan berat $0,3 \mathrm{~g}$ hingga $4 \mathrm{~g}$. Batu tersebut mungkin sulit untuk dihilangkan, tetapi biasanya tidak berbahaya. Tonsillolith bisa unilateral atau bilateral. Terjadi pada orang dewasa muda dan jarang terjadi pada anakanak. Etiologi tidak diketahui dengan pasti, telah terbukti bahwa batu tonsila berkembang dari massa epitel yang tergabung dengan serum, sisa makanan dan koloni bakteri. Laporan kasus ini mengenai pasien dengan diagnosapalatine tonsilloliths. Seorang wanita berusia 55 tahun datang ke klinik swasta, dia mengeluh sulit menelan, sakit tenggorokan, gatal di tonsila palatina kanan, sensasi seperti ada benda asing. Pada pemeriksaan klinis, tonsillolith superfisial dapat dilihat sebagai massa keras berwarna putih pada tonsilapalatina kanan, dengan sedikit peradangan tonsila. Ukuran tonsillolith adalah $2 \times 3 \times 1 \mathrm{~mm}$. Penanganan biasanya pengangkatan batu tonsila dan obat kumur tanpa alkohol, antibiotik,dengan berkumur membantu penyembuhan luka. Setelah tonsil diangkat, seminggu kemudian penyembuhan luka berlangsung dengan baik. Tonsil palitinakanan terlihat sehat, penyembuhan luka normal tidak ada sakit tenggorokan, prognosa bagus. Penyembuhan akan sempurna bila makan makanan lunak. Keberhasilan pengobatan tergantung pada kerja sama yang baik antara pasien dan dokter.

Kata kunci: tonsillolith palatine, sakit tenggorokan, diangkat

\section{INTRODUCTION}

Tonsilloliths has another terms are tonsil stones, tonsil concretions, calcification of the tonsillaror simply called liths ${ }^{1}$. Tonsilloliths are stones that caused by an accumulation of sulfur-producing bac- teria, fungus, desquamated epithelial cells, food debris, and mucus that collect in the tonsillar crypts ${ }^{1-}$ ${ }^{4}$. Tonsilloiths can be located in the palatine tonsil (palatine tonsilloliths) ${ }^{4,5}$, nasopharyngeal tonsil (adenoid $)^{3}$, sometimes discovered in lingual tonsil ${ }^{4,5}$, more frequently in palatine tonsilloliths. It can be 
discovered such as unilateral or bilateral location ${ }^{2,3,5}$. Tonsilloliths have been recorded weighing from $0,3 \mathrm{~g}$ to $4 \mathrm{~g}$, the average size of tonsilloliths was $4 \mathrm{~mm}$ (range: $3-11 \mathrm{~mm})^{1}$. Tonsilolith are white mass calcified structure ${ }^{1,4,6,7}$. They may be difficult to remove, but are usually not harmful. Tonsilloliths can occur in both genders and all age of groups otherwise more frequently in adults than in children, male and female ratio of 1:1. No surgical treatment needed, sometime are able to remove by gargles vigorously ${ }^{1}$. Etiology is unknown ${ }^{1,6,8}$, it has been shown that the calcification develop with mass of desquamated epithelium cells, serum, food debris and bacterial colony ${ }^{1-5}$. The purpose of this study is to manage the palatinetonsilloliths, the problems: difficult to swallow, sore throat and itching in right palatine tonsil.

\section{CASE REPORT}

A 55 years old female came to a private clinic, she complained difficult to swallow, sore throat, itching in right posterior tonsil, a foreign body-like sensation. Past history revealed an approximately a year of slight swallowing pain. On general physical examination observed that she is a normal condition. Extra oral examination: we check the region of head and neck: we may check upper respiratory system, and normal. The right submandibular lymph nodes is detected, Intra oral examination oral hygiene rare, there is white or yellowish mass in the right palatine tonsillar, difficult to remove, tonsil swelling. A foreign body sensation may also be an asymptomatic condition, with solid detection upon excavator dental tools, the foreign body is hard in right intra palatine tonsillar.

\section{CASE MANAGEMENT}

Management of tonsilloliths is dependent on size, symptoms, and informed patient discussion. In this case, she complained difficult to swallow, sore throat, itching in right posterior tonsil, a foreign body-like sensation. The patient's past history revealed an approximately 1 -year of slight swallowing pain. The right submandibular lymph nodes are detected (palpable neck lymphadenopathy): no pain. Oral manifestations of the patient are oral hygiene rare, tonsillar slightly inflammation, there is a white or yellowish mass in the right intra palatinetonsil. The palpating is solid (by excavator), no surgical intervention was needed. The diagnosisis palatine tonsilloliths. The treatment is excavated of white mass from right intra palatine tonsillar. The physical of tonsillolith revealed following: shape irregular, rough surfaces, semi hard consistency and the size is $2 \times 3 \times 1 \mathrm{~mm}$.

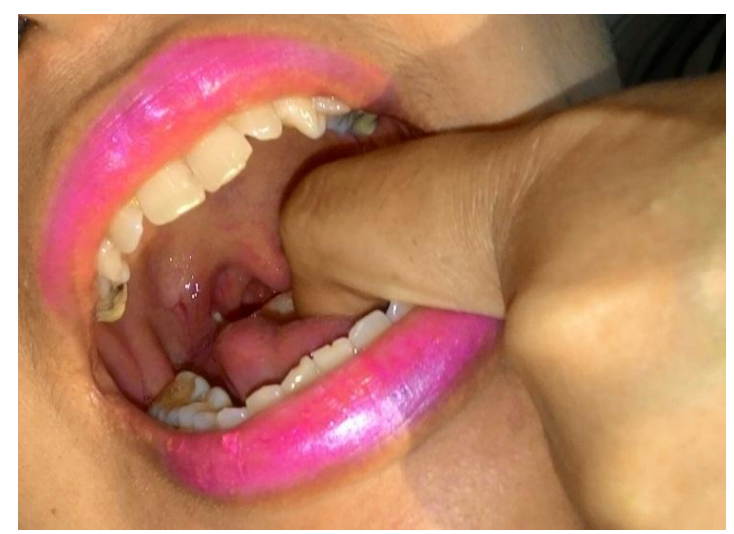

Figure 1. White or yellowish mass in the right palatine tonsillar $^{10}$

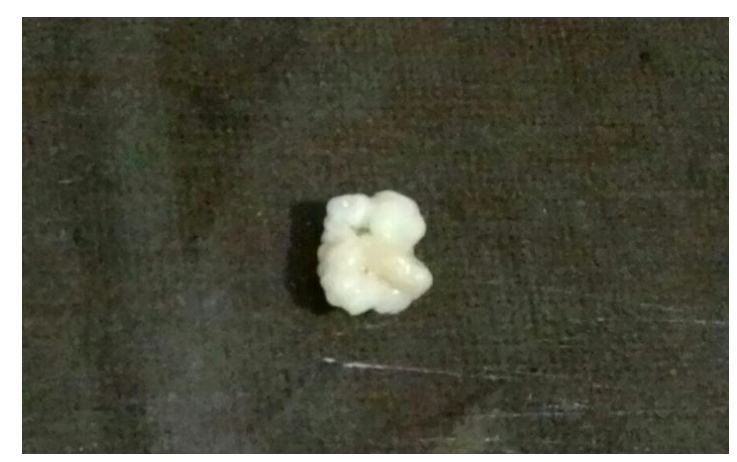

Figure 2. White or yellowish mass aspalatine tonsilloliths $^{10}$

The treatment are antibiotic, analgesic, mouthwash, Chlorhexidine can be used as a valuable antiseptic agent. Good oral hygiene instruction is another important issue for easier healing. Two weeks later the wound healing is well. Her right tonsillar palatine looks healthy, no red anymore, prognosis is good. Wound healing is normal. Healing will be perfect when finding the cause accompanying clinical symptoms.

\section{DISCUSSION}

Palatine tonsilloliths or tonsil stones are calcified bodies that develop in enlarged tonsillar crypts. Palatine tonsioliths is unpleasant condition from the mouth that is detected by the patient who complained difficult to swallow, sore throat, itching in right posterior tonsil, a foreign body-like sensation. This undesirable conditi-on is a common complaint for both genders ${ }^{5,7}$. The age range was for all age groups, male and female ratio of 1:1. Tonsilloliths 
can occur in up to $10 \%$ of the population. The population of patients with tonsilloliths is range 10 to 77 years, with man occurrence 46 years ${ }^{1}$.

Palatine Tonsilloliths are stones that logded in tonsillar palatine crypt, tonsilloliths are stones that caused by an accumulation of sulfur-producing bacteria, fungus, desquamated cells, food debris, and mucus that collect in the tonsillar crypts. Etiology of tonsillolith is unknown and located in the peritonsillar region. Tonsillolith show differences size is 3-11 $\mathrm{mm}$, the shape are round, oval, square, and irregular. The consistency is gel to solid and color is white or yellowish mass. They are usually asymptomatic but can be associated with sore throat, difficulty in swallowing, and neck pain. A patient with the right side palatine tonsillar pain, distributed within the tonsillar crypt, fossa and pharynx. Tonsilloliths are associated with recurrent inflammation ${ }^{8}$.

Treatment in this case report by detected etiology, treatment is usually removal of the tonsilloliths by

\section{REFERENCES}

1. Bamgbose BO, Ruprecht A, Hellstein J, Timmons $\mathrm{S}$, Qian F. The prevalence of tonsillolith and other soft tissue calcifications in patient attending oral and ma-xillofcial radiology clinic of the University of Iowa. ISRN Dent 2014; 2014: 1-9.

2. Fauroux MA, Mas C, Tramini P, Torres JH. Prevalence of palatine tonsilloliths: a retrospective study on 150 consecutive CT examinations. Dentomaxil-lofac Radiol 2013; 42(7): 1-3.

3. Ram S, Siar CH, Ismail SM, Prepageran N. Pseudo bilateral tonsilloliths: case report and review of the literature. J Oral Surg Oral Med Oral Pathol Oral Radiol Endod. 2004: 98 (1): 110-4.

4. Bai KY, Kumar BV, Tonsillolith: a polymicrobial biofilm. Med J Armed Forces India. 2015 Jul; 71 (suppl 1): 95-8.

5. Takahashi A., Sugawara C., Kudoh K., Y. Yamamura, Ohe $\mathrm{G}$, et al. Lingual tonsillolith: prevalence and imaging characteristics evaluated on 2244 pairs of panoramicradiographs and CT images. Dentomaxillofac Radiol J 2018; 47(1):1-7.

6. Takahashi A, Sugawara C, Kudoh T, Uchida D, Tamatani T, et al. Prevalence and imaging characteristic of palatine tonsilloliths detected by CT in 2,873 consecutive patients. The Scientific World J 2014; 2014: 1-4. excavated (small) or curettage (big). Dentist should be aware of tonsilloliths as possible cause of orofacial pain or glossopharyngeal pain, but the cause and pathogenesis still remain unknown ${ }^{11}$. The patient's past history revealed an approximately 1year of slight swallowing pain. According to Dykes ${ }^{9}$, tonsillolith are associated with recurrent inflammation as tonsillitis, this corresponds to the patient condition, that the patient had recurrent inflammation as well as a year ago. Tonsilloliths are thought to result from unresolved ton-sillitis; infectious agents 5 .

This describes offers an alternate etiology to tonsillolith formation by salivary glands obstruction, chronic inflammation or whenever low body defense. Successful treatment depends on good cooperation between the patient and the doctor.

7. Misirlioglu M, Nalcaci R, Adisen MZ, Yardimci S, Bilateral and pseudobilateral tonsilloliths: three dimensional imaging with cone-beam computed tomo-graphy. Imaging Sci Dent 2013; 43(3): 163-9.

8. Dykes M, Izzat S, Pothula V. Giant Tonsilloith-a rare cause of Dysphagia. J Surg Case Rep 2012; 4: 1-4.

9. Balaji BB, Avinash TML, Avinash CKA, Avinash A, Chittaranjan B. Tonsillolith: a panoramic radiograph presentation. J.Clin Diagn Res 2013; 7(10): 2378-9.

10. Sieber S, Hat J, Brakus I, Biocic J, Brajdic D, Zajc I, et al. Tonsilolithiasis and orofacial pain. Gerodontology 2012; 29(2): 1157-60. 